\title{
EFFICACY OF Bacillus thuringiensis VAR. KURSTAKI (DIPEL 2X), NEEM EXTRACT AND CHLORPYRIFIOS- METHYL (RELDAN) AGAINST COTTON BOLLWORMS
}

Abd El Ghaffar, M.M. ${ }^{1}$; Ibrahim,I.L. ${ }^{1}$; A. A. Abd El all ${ }^{2}$ and O. I.A. Diab ${ }^{2}$

1- Dept. of Plant Protection, Faculty of Agric., Al-Azhar Univ.

2- Bollworms Res. Dept., Plant Protection Research Institute.

\begin{abstract}
The efficacy of Bacillus thuringensis subsp. Kurstaki (Dipel 2X), neem extract (Azadirachtin) and reldan (Chlorpyrifios-methyl) for management of cotton bullworms (Earias insulana "Boisd" and Pectinophora gossypiella "Saunders") were studied under field condition at Shubrakheit region, Behira Governorate during 2004-2005. Dipel 2X (200 g/Fed.) was equally effective as the chemical insecticide (Reldan) to protecting the fruiting flowers and green bolls of the cotton variety "Giza 88". Neem extract was less effective than Dipel $2 X$ compared with untreated control. The highest yield of cotton was obtained by using the chemical insecticide treatment followed by Dipel 2X and neem extract compared with untreated control. Dipel 2X persisted well under the field conditions with identical half life time of 10 days in cotton fields compared to Reldan and neem extract.
\end{abstract}

\section{INTRODUCTION}

Cotton is the major economic crop in Egypt. The most yield and quality losses are caused by insect pests, especially spiny bollworm (Earias insulana "Boisd") and pink bollworm (Pectinophora gossypiella "Saunders"). The damage caused by these two pests are enhanced due to the attack to the fruiting part (flowers and green bolls) allover the cotton season. Due to the well known hazards of wide use of chemical insecticides in cotton fields, it appears of great value to look for effective alternative means for control. In this respect, increased attention have recently been given to the pathogenic bacteria Bacillus thuringiensis Kurstaki and neem (azadirachtin) causing insect diseases, which represents a promising alternative and has advantages, especially in reducing some of the environmental problems induced by insecticides. Therefore this work aimed. Balakrishan et al. (2005) study the effectiveness of some commercial products of B.t.k. including local product named (Dipel-2X) in reducing percent of bolls infestation by the two insects.

\section{MATERIAL AND METHODS}

The present study concerned with the efficiency of the bioinsecticides (Dipel 2X), neem extract and chemical insecticides (Reldan) on the spiny bollworm, Earias insulana and pink bollworm, Pectinophora gossypiella under field condition.

The field experiments were carried out during two successive cotton season of 2003-2004 and 2004-2005 at Shubrakhit region Behira Governorate to evaluate the efficiency of different control programs against the spiny and pink bollworms during season 2004-2005. 
Cotton variety "Giza 88" was planted in 26"th March Agricultural practices were carried out as recommended by Ministry of Agriculture, and the experimental area did not receive any insecticide.

\section{Pesticides tested:}

a) Dipel-2X (200 gr/fed. WP), the potency equal 32.000 international unit, obtained from May trade company Giza, Egypt.

b) Neem extract $\left(100 \mathrm{~cm}^{3} / \mathrm{fed}\right.$. EC) quantitatirely the azadirachtin standard $2 \%$ was purchased from Trifolio-MGmbH, Belgium chemical structure: $\mathrm{C}_{33} \mathrm{H}_{44} \mathrm{O}_{16}$

c) Reldan (600 mg/fed. EC), common name: Chlorpyrifios-methyl.

The experimental design was randomized complete blocks with four replicates for each treatment, each of $42 \mathrm{~m}^{2}$. A 20 litre knapsack sprayer was used for application of insecticides compared with 4 replicates as control (untreated area). The spray schedule program was automatically applied every ten days started at $26^{\text {th }}$ June 2004 until the end of season. Twenty five flowers or green cotton bolls were collected for each replicate and checked after $48 \mathrm{hr}$ and ten days of treatment and compared with untreated control.

Total number of spiny bollworm (SBW) and pink bollworm (PBW) larvae as well as reduction \% of infested bolls were estimated after each application and at the end of the season for each tested compound where seven sprays were applied. Reduction percentage of all counted larvae (SBW and PBW) were calculated according to Hinderson and Tilton formula (1955).

No. of larvae of treatment after spray $x$ No. of larvae of control before spray

Reduction $\%=1-\frac{\text { No. of larvae of treatment before spray } \times \text { No. of }}{100}$ larvae of control after spray

\section{RESULTS AND DISCUSSION}

\section{I- Effect of Dipel 2X, Neem extract and Reldan on bollworms:}

Field experiments were carried out during two successive cotton seasons 2004 \& 2005 to evaluate the efficacy of Neem extract, Dipel $2 X$ and Reldan against SBW (E. insulana) and PBW ( $P$. gossypilla) at Shubrakhit district, Behira Governorate. The larval population of both pests and reduction of its numbers after application of the tested compounds are represented in Tables (1, 2, 3 \& 4) and illustrated in Fig. (1).

\section{I.1. Reduction in bollworm population:}

\section{I.1.1. Reduction in spiny bollworm Earias insulana:}

During 2004 season, data in Table (1) appeared that all tested compound revealed good protection of cotton flowers spiny bollworm attack and resulted in higher reduction percentage of infestation. After the $2^{\text {nd }}$ spray reduction \% of infestation in cotton flowers ranged between $71.42 \%$ for Dipel, $71.42 \%$ for Neem, $71.42 \%$ for Reldan in the different compound. Meanwhile, continuous application at 10 days interval with compound resulted in low infestation in cotton bolls spiny bollworm. Mean reduction \% of infestation in flowers and cotton bolls ranged between $66.63 \%, 18.41 \%$ and $65.09 \%$ for the Dipel 2X, Neem extract and Reldan, respectively (Table, 1). 
J. Agric. Sci. Mansoura Univ., 32 (1), January, 2007

T1-2 
Mahmoud, M.A. et al.

T3-4 
J. Agric. Sci. Mansoura Univ., 32 (1), January, 2007

F1 
These results supported by Luo et al. (1986), they stated that the field application of commercial formulation of $B$. thuringensis sub Jurstaki produced $42-53 \%$ reduction in the number of cotton bolls infested with $P$. gossypiella. The application of neem and $B$. thuringensis gave effective control. Satisfactory control of the bollworm (Earies spp. and $P$. gossipella) and an increase in cotton yield were also obtained by applying combination of neem, B.t. and an $84 \%$ reduced rate of synthetic pyrethroid.

Taking into account the percentage reduction of infestation with spiny bollworm through 2005 season, it is clear that the early application of tested on cotton flowers compound resulted lowest level of infestation with spiny bollworm. Reduction \% of infestation was $71.42 \%$ for Dipel, $71.42 \%$ for Neem and $90.47 \%$ for Reldan respectively. Mean reduction percentage of infestation in flowers and cotton bolls was almost increased with increase in the cotton age. It was ranged between $46.15 \%$ for Dipel $2 \mathrm{X}, 71.86 \%$ for Neem extract and $78.95 \%$ for Reldan respectively (Table 2 ).

Our results disagree with Rawale et al. (2002), they were reported that the performance of neem seed extract $(5 \%)$ was found poor against the bollworm under field condition.

\section{I.1.2. Reduction in pink bollworm, $P$. gossypiella:}

During 2004 season, data in Table (3) appeared that all tested compound revealed good protection of cotton flowers pink bollworm attack and resulted in higher reduction percentage of infestation. After the $2^{\text {nd }}$ spray, reduction $\%$ of infestation in cotton flowers ranged between $42.85 \%, 42.85 \%$ and $61.90 \%$ with Dipel, Neem and Reldan, respectively. Meanwhile, continuous application at 10 days interval with compound Dipel 2X, Neem extract and Reldan resulted in low infestation in cotton bolls pink bollworm. Mean reduction \% of infestation in flowers and cotton bolls ranged between $55.56 \%$ for Dipel, $54.20 \%$ for Neem and $61.90 \%$ for Reldan, respectively.

Rawalle et al. (2002) stated that after $1^{\text {st }}$ and $3^{\text {rd }}$ spraying minimum bollworm infestation in fruiting bodies and boll-infestation (16-61\%) at harvest was shown by plots sprayed by chlorpyriphos 0.03 percent.

Taking into account the percentage reduction of infestation with early application on cotton flowers with the different compound resulted in the lowest level of infestation with pink bollworm. Reduction percentage of infestation in cotton flowers followed discendingly by compound Dipel 2X, Neem extract and Reldan respectively $25.00 \%$ for Dipel, $50.00 \%$ for Neem and $75.00 \%$ for Reldan). Mean reduction percentage of infestation in flowers and cotton bolls was almost increased with increase in the cotton age, it was ranged between $34.54 \%$ for Dipel, $42.34 \%$ for Neem and $54.44 \%$ for Reldan, respectively (Table 4).

These data were fortified by Rashad et al. (1991), they tested crude extract of the Melia uzedarach (Meliaceae) leaves at different concentrations against cotton bollworms, E. insulana (Boisd.) and P. gossypiella (Sauders). The results indicated that highest concentration increased mortality of newly hatched larvae of the two species and reduced moths emergence. Due to the toxicity (reldan or Dipel 2x) or antifeeding effect (neem extract) these substances could be used as pest control agents in integrated pest control programs but they still require further studies under field conditions. 
On the other hand, the data recorded by Gupta et al. (1998 \& 1999) on neem extract alone or in combination with B.t formulations or convention insecticides failed to check the incidence of bollworms.

\section{REFERENCES}

Balakrishan, N.; Baskaran, R.K.M. and Magadevam, N.R. (2005). Evaluation of management modules of bollworms on cotton under rainfed conditions. Department of Agri. Entomology, T.N.A.U., ACPRI, Killikulam-628-252.

Gupta, G.P. and Lal, R. (1998). Utilization of newer insecticides and neem in cotton pests management system. Annals-of-plant-protection-Science. 1998; 6 (8): 155-160.

Gupta, G.P.; Katigar, K.N. and Kirti-Sharina (1999). Neem in the management strategies of insect pest of cotton. Azadirachta-indica-A-Juss. 1999; 177-189.

Hinderson, C.F. and E.W. Tilton (1955): Test with acaricides against the bran wheat mites. J. Econ. Entomol. 48: 157-161.

Luo, S.B.; J.P. Van; C.J. Chai; S.P. Liang; Y.M. Zhang; Y. I Zhang and G.K. Le (1986). Control of pink bollworm Pectinophora gossypiella with Bacillus thuriniensis in cotton field. J. Biol. Control, 2 (4): 167-168.

Rashad, Amira M.; Taher, Suzan H.; Naguib, Sonia M. and Abdel-Salam, N.M. (1991). Effect of melia azedarach extract on $E$. insulana (Boisd.) and $P$. gossypiella (Saunders). Egypt. J. Biol. P. Cont., 1: 117-120.

Rawale, B.N.; Kausale, P.P.; Munde, A.T.; Kedar, P.B.; Sonkamble, M.M. and Waghonode, D.B. (2002). Efficacy of insecticides and neem seed extract against cotton bollworms on NHH-44. Journal-of-Soils-and Crops. 2002; 12 (1): 75-77.

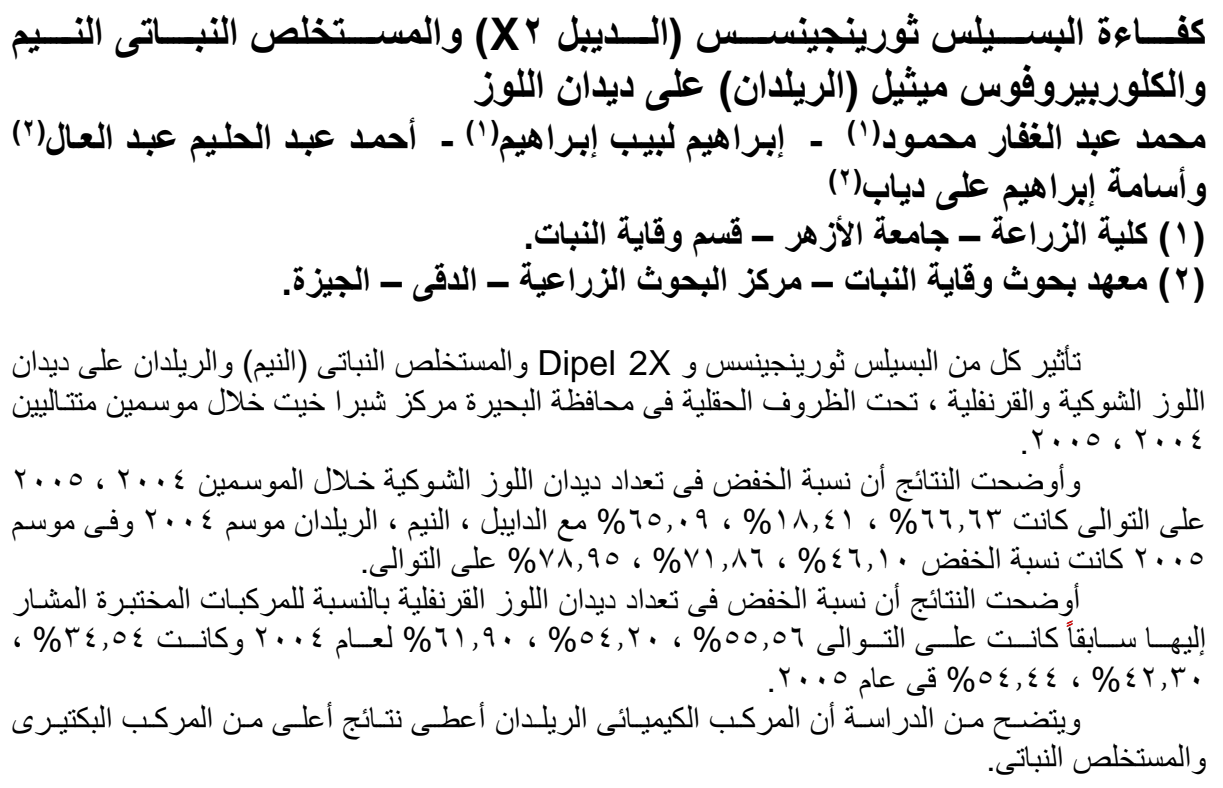


Table (1): Effect of Dipel 2X, Neem extract and Chlorpyrifios-methyl (Reldan) on spiny bollworm larvae infested different fruit structures of cotton at Shubrakit district, El-Behira Governorate during 2004 season.

\begin{tabular}{|c|c|c|c|c|c|c|c|c|c|}
\hline \multirow[b]{3}{*}{ Treatment } & \multirow{3}{*}{$\begin{array}{c}\text { Number } \\
\text { of all } \\
\text { larvae } \\
\text { before } \\
\text { spray }\end{array}$} & \multicolumn{8}{|c|}{ Number of all larvae and reduction after 10 days from the indicated spray after spray(s) } \\
\hline & & \multicolumn{2}{|c|}{ Flowers } & \multicolumn{5}{|c|}{ Bolls } & \multirow{2}{*}{\begin{tabular}{|c|} 
Mean \\
Reduction \%
\end{tabular}} \\
\hline & & $\begin{array}{c}\text { Reduction } \\
\text { after } 1^{\text {st*}} \\
\text { spray }\end{array}$ & $\begin{array}{c}\text { Reduction \% } \\
\text { after } 2^{\text {nd } d \star \star} \\
\text { spray }\end{array}$ & $\begin{array}{l}\text { Reduction \% } \\
\text { after } 3^{\text {rd }} \text { spray }\end{array}$ & $\begin{array}{c}\text { Reduction } \% \\
\text { after } 4^{\text {th }} \text { spray }\end{array}$ & $\begin{array}{l}\text { Reduction } \% \\
\text { after } 5^{\text {th }} \text { spray }\end{array}$ & $\begin{array}{l}\text { Reduction \% } \\
\text { after } 6^{\text {th }} \text { spray }\end{array}$ & $\begin{array}{l}\text { Reduction \% } \\
\text { after } 7^{\text {th }} \text { spray }\end{array}$ & \\
\hline Dipel-2X & 2 & 50.00 & 71.42 & 60.00 & 60.00 & 75.00 & 75.00 & 75.00 & $66.63 \mathrm{~B}$ \\
\hline Neem & 1 & 62.50 & 71.42 & -20.00 & -60.00 & 50.00 & 00.00 & 25.00 & $18.41 \mathrm{C}$ \\
\hline Reldan & 2 & 50.00 & 71.42 & 60.00 & 70.00 & 75.00 & 66.66 & 62.50 & $65.09 \mathrm{~A}$ \\
\hline $\mathbf{F}$ & \multicolumn{9}{|c|}{0.0872} \\
\hline L.S.D. 0.05 & \multicolumn{9}{|c|}{0.1745} \\
\hline
\end{tabular}

- Values followed by the same letter are not significantly
$* \star \star$

Table (2): Effect of Dipel 2X, Neem extract and Chlorpyrifios-methyl (Reldan) on spiny bollworm larvae infested different fruit structures of cotton at Shubrakit district, El-Behira Governorate during 2005 season.

\begin{tabular}{|c|c|c|c|c|c|c|c|c|c|}
\hline \multirow[b]{3}{*}{ Treatment } & \multirow{3}{*}{$\begin{array}{c}\text { Number } \\
\text { of all } \\
\text { larvae } \\
\text { before } \\
\text { spray }\end{array}$} & \multicolumn{8}{|c|}{ Number of all larvae and reduction after 10 days from the indicated spray after spray(s) } \\
\hline & & \multicolumn{2}{|c|}{ Flowers } & \multicolumn{5}{|c|}{ Bolls } & \multirow{2}{*}{\begin{tabular}{|c|} 
Mean \\
Reduction \%
\end{tabular}} \\
\hline & & 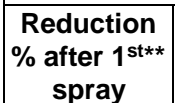 & 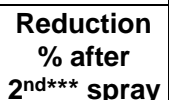 & $\begin{array}{c}\text { Reduction \% } \\
\text { after } 3^{\text {rd }} \text { spray }\end{array}$ & $\begin{array}{c}\text { Reduction \% } \\
\text { after } 4^{\text {th }} \text { spray }\end{array}$ & $\begin{array}{l}\text { Reduction \% } \\
\text { after } 5^{\text {th }} \text { spray }\end{array}$ & $\begin{array}{l}\text { Reduction \% } \\
\text { after } 6^{\text {th }} \text { spray }\end{array}$ & $\begin{array}{c}\text { Reduction \% } \\
\text { after } 7^{\text {th }} \text { spray }\end{array}$ & \\
\hline Dipel-2X & 2 & 50.00 & 71.42 & 60.00 & 16.66 & 25.00 & 33.33 & 66.66 & $46.15 \mathrm{C}$ \\
\hline Neem & 2 & 75.00 & 71.42 & 60.00 & 66.66 & 62.50 & 83.33 & 83.33 & $71.86 \mathrm{~B}$ \\
\hline Reldan & 3 & 83.33 & 90.47 & 73.33 & 77.77 & 83.33 & 77.77 & 66.66 & $78.95 \mathrm{~A}$ \\
\hline $\mathrm{F}$ & \multicolumn{9}{|c|}{0.7637} \\
\hline L.S.D. 0.05 & \multicolumn{9}{|c|}{0.02837} \\
\hline
\end{tabular}

- Values followed by the same letter are not significantly $\quad$ ** Date of $1^{\text {st }}$ spray (26/6/2005)

*** Spray followed continuously ten days intervals (the last spray $(25 / 8 / 2005)$ 
Table (3): Effect of Dipel 2X, Neem extract and Chlorpyrifios-methyl (Reldan) on pink bollworm larvae infested different fruit structures of cotton at Shubrakit district, El-Behira Governorate during 2004 season.

\begin{tabular}{|c|c|c|c|c|c|c|c|c|c|}
\hline \multirow[b]{3}{*}{ Treatment } & \multirow{3}{*}{\begin{tabular}{|c|} 
Number \\
of all \\
larvae \\
before \\
spray
\end{tabular}} & \multicolumn{8}{|c|}{ Number of all larvae and reduction after 10 days from the indicated spray after spray(s) } \\
\hline & & \multicolumn{2}{|c|}{ Flowers } & \multicolumn{5}{|c|}{ Bolls } & \multirow{2}{*}{$\begin{array}{c}\text { Mean } \\
\text { Reduction \% }\end{array}$} \\
\hline & & \begin{tabular}{c|}
$\begin{array}{c}\text { Reduction } \\
\% \text { after } 1^{\text {st }} \\
\text { spray }\end{array}$ \\
\end{tabular} & \begin{tabular}{|c|} 
Reduction \\
$\%$ after \\
$2^{\text {nd*** spray }}$
\end{tabular} & $\begin{array}{c}\text { Reduction \% } \\
\text { after } 3^{\text {rd }} \text { spray }\end{array}$ & $\begin{array}{l}\text { Reduction \% } \\
\text { after } 4^{\text {th }} \text { spray }\end{array}$ & $\begin{array}{l}\text { Reduction \% } \\
\text { after } 5^{\text {th }} \text { spray }\end{array}$ & $\begin{array}{l}\text { Reduction \% } \\
\text { after } 6^{\text {th }} \text { spray }\end{array}$ & $\begin{array}{l}\text { Reduction \% } \\
\text { after } 7^{\text {th }} \text { spray }\end{array}$ & \\
\hline Dipel-2X & 2 & 33.33 & 42.85 & 60.00 & 75.00 & 77.77 & 33.33 & 66.66 & $55.56 \mathrm{~B}$ \\
\hline Neem & 3 & 33.33 & 42.85 & -6.66 & 83.33 & 70.37 & 77.77 & 77.77 & $54.20 \mathrm{~B}$ \\
\hline Reldan & 3 & 33.33 & 61.90 & 73.33 & 83.33 & 70.37 & 77.77 & 33.33 & $61.90 \mathrm{~A}$ \\
\hline $\mathbf{F}$ & \multicolumn{9}{|c|}{0.9053} \\
\hline L.S.D. 0.05 & \multicolumn{9}{|c|}{0.6721} \\
\hline
\end{tabular}

Table (4): Effect of Dipel 2X, Neem extract and Chlorpyrifios-methyl (Reldan) on pink bollworm larvae infested different fruit structures of cotton at Shubrakit district, El-Behira Governorate during 2005 season.

\begin{tabular}{|c|c|c|c|c|c|c|c|c|c|}
\hline \multirow[b]{3}{*}{ Treatment } & \multirow{3}{*}{$\begin{array}{c}\text { Number } \\
\text { of all } \\
\text { larvae } \\
\text { before } \\
\text { spray }\end{array}$} & \multicolumn{8}{|c|}{ Number of all larvae and reduction after 10 days from the indicated spray after spray(s) } \\
\hline & & \multicolumn{2}{|c|}{ Flowers } & \multicolumn{5}{|c|}{ Bolls } & \multirow{2}{*}{\begin{tabular}{|c|} 
Mean \\
Reduction \%
\end{tabular}} \\
\hline & & \begin{tabular}{|c}
$\begin{array}{c}\text { Reduction \% } \\
\text { after } 1^{\text {st } \star \star} \\
\text { spray }\end{array}$ \\
\end{tabular} & $\begin{array}{c}\text { Reduction \% } \\
\text { after } 2^{\text {nd } d \star \star} \\
\text { spray }\end{array}$ & $\begin{array}{l}\text { Reduction \% } \\
\text { after } 3^{\text {rd }} \text { spray }\end{array}$ & $\begin{array}{l}\text { Reduction \% } \\
\text { after } 4^{\text {th }} \text { spray }\end{array}$ & $\begin{array}{c}\text { Reduction \% } \\
\text { after } 5^{\text {th }} \text { spray }\end{array}$ & $\begin{array}{l}\text { Reduction \% } \\
\text { after } 6^{\text {th }} \text { spray }\end{array}$ & $\begin{array}{l}\text { Reduction \% } \\
\text { after } 7^{\text {th }} \text { spray }\end{array}$ & \\
\hline Dipel-2X & 2 & 40.00 & 25.00 & 43.75 & 35.71 & -25.00 & 43.75 & 78.57 & $34.54 \mathrm{~B}$ \\
\hline Neem & 2 & 40.00 & 50.00 & 62.50 & 14.28 & 50.00 & 43.75 & 35.57 & $42.30 \mathrm{~B}$ \\
\hline Reldan & 2 & 10.00 & 75.00 & 66.66 & 78.57 & 50.00 & 43.75 & 57.14 & $54.44 \mathrm{~A}$ \\
\hline $\mathbf{F}$ & \multicolumn{9}{|c|}{0.0027} \\
\hline L.S.D. 0.05 & & & & & 0.1522 & & & & \\
\hline
\end{tabular}

- Values followed by the same letter are not significantly

** Date of $1^{\text {st }}$ spray $(26 / 6 / 2005)$

*** Spray followed continuously ten days intervals (the last spray $(25 / 8 / 2005)$ 
Mahmoud, M.A. et al.

$\begin{array}{lllllll}703 & 704 & 705 & 706 & 707 & 708 & 709\end{array}$

$\begin{array}{lllllll}703 & 704 & 705 & 706 & 707 & 708 & 709\end{array}$ 